\title{
Ral-GDS-Related Protein
}

National Cancer Institute

\section{Source}

National Cancer Institute. Ral-GDS-Related Protein. NCI Thesaurus. Code C113578.

Ral-GDS-related protein ( $473 \mathrm{aa}, \sim 52 \mathrm{kDa}$ ) is encoded by the human RGL4 gene. This protein plays a role in in the metabolism of guanine nucleotides. 